\title{
Field Evaluation of Application Variables and Plant Density for Bell Pepper Pest Management
}

\author{
R. C. Derksen, S. Vitanza, C. Welty, S. Miller, M. Bennett, H. Zhu
}

\begin{abstract}
Bell peppers are a valuable vegetable crop in the U.S. Management of pepper insects and diseases relies on chemical control options. Because there are relatively few chemical options available for pepper pest management, it is critical to make efficacious application of pesticides. Foliar spray coverage and spray retention in the middle and bottom of bell pepper canopies were compared using fluorescent dyes and food coloring, respectively. Several delivery systems were evaluated, including air-induction and twin-fan nozzles, air-assisted delivery with conventional hydraulic nozzles, and pneumatic atomization nozzles producing electrically charged sprays. Plant spacing between and within rows was evaluated in the second year of the application trial. Travel speeds of 6.4 and $12.9 \mathrm{~km} \mathrm{~h}^{-1}$ were also evaluated. Faster travel speeds did not significantly affect spray retention in twin-row canopies. The electrostatic sprayer produced the greatest differences in deposits between the middle and bottom of the canopy. Although there was no more than a $25 \mathrm{~cm}$ difference between leaves sampled from the middle and bottom canopy locations, spray retention on foliage in the bottom canopy locations had significantly lower retention than the middle canopy for almost all sprayer types. Despite differences in atomization characteristics, the performance of the twin-fan nozzle and the air-induction nozzle treatments were similar. Air-assisted delivery provided no advantage in the amount of spray retained on the foliage, but it produced more desirable spray quality on foliage and resulted in more spray retained on whole fruit.
\end{abstract}

Keywords. Air-assist, Coverage, Deposit, Electrostatic, Pepper, Spray.

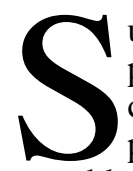
uccessful bell pepper production depends on the appearance of the fruit, absence of insect and mold contamination, fruit size, and overall yield. Key bell pepper pests in Ohio include the European corn borer and bacterial spot. The production system affects pepper productivity and health (Batal and Smittle, 1981; Stofella and Bryan, 1988; Russo, 1991; Gaye et al., 1992; Locascio and Stall, 1994; Jolliffe and Gaye, 1995). Most pepper production systems involve application of pest management materials with ground-based equipment. While higher plant stand densities increase fruit yields, increasing canopy density may inhibit the ability to protect lower areas of the canopy.

Although evidence of the influence of application methodologies on pest management and plant production has been

Submitted for review in April 2007 as manuscript number PM 6980; approved for publication by the Power \& Machinery Division of ASABE in November 2007.

Names are necessary to report factually on available data; however, the USDA neither guarantees nor warrants the standard of the product, and the use of the name by USDA implies no approval of the product to the exclusion of others that may also be suitable.

The authors are Richard Charles Derksen, ASABE Member Engineer, Agricultural Engineer, USDA-ARS Applied Technology Research Unit, Wooster, Ohio; Salvador Vitanza, Extension Agent-IPM, Texas A\&M University Extension IPM, Clint, Texas; Celeste Welty, Entomologist and Professor, Department of Entomology, Sally Miller, Plant Pathologist and Professor, Department of Plant Pathology, and Mark Bennett, Horticulturalist and Professor, Department of Horticulture and Crop Science, The Ohio State University, Columbus, Ohio; and Heping Zhu, ASABE Member Engineer, Agricultural Engineer, USDA-ARS, Applied Technology Research Unit, Wooster, Ohio. Corresponding author: Richard C. Derksen, USDA-ARS ATRU, Agricultural Engineering Bldg., 1680 Madison Ave., Wooster, OH 44691; phone: 330-263-3869; fax: 330-263-3670; e-mail: rich.derksen@ars.usda.gov. reported for several different crops (Jeffers et al., 1982; Zehnder and Speese, 1991; Perez et al., 1995; Welty et al., 1995; Ebert et al., 2004; Derksen et al., 2001; Mueller et al., 2002), there is little published research on the influence of application methods on pepper production. Growers typically use either flat-fan or cone hydraulic nozzles to apply pesticides in vegetable crops. There are few guidelines available on selection of nozzles and other application variables to provide a desired level of efficacy. Himel (1969) reported the importance of one spray parameter, droplet size, on the efficacy of pesticide sprays. Several studies reported the influence of application methods on deposits in various crops treated with conventional ground sprayers (Azimi et al., 1985; Ozkan et al., 2006; Smith, 1992; Smith et al., 2000; Zhu et al., 2004; Zhu et al., 2006). Researchers have consistently found that air-assisted delivery improves canopy penetration in row crops compared to conventional delivery at the same rate of application (Derksen et al., 2001; Mueller et al., 2002; Piché et al., 2000; Womac et al., 1992). It may, therefore, be beneficial in pepper pest management.

Pepper pest management programs may also benefit from application systems that charge spray particles. Giles and Blewett (1991) and Perez et al. (1995) reported that electrically charged sprays increased spray deposits compared to non-charged sprays in field-grown strawberries and cabbage. Herzog et al. (1983) showed that an air-assist, electrostatic sprayer controlled cotton insect pests as well as a conventional hydraulic, broadcast sprayer using only onehalf as much active ingredient. There was no significant difference in yields between the reduced-rate electrostatic treatment and the full-rate conventional treatment. Coates and Palumbo (1997) reported measurable differences in deposits on cantaloupe leaf undersides between air-assisted 
electrostatic and air curtain treatments and the conventional broadcast treatment. Differences in pesticide deposits and biological efficacy between sprayers decreased as canopy density increased.

Foliar coverage and deposition produced by twin-fan or dual-fan nozzles and low-drift, air-induction nozzles has not been widely reported for insecticide or fungicide delivery. Zhu et al. (2002) demonstrated that inclining a single fan spray pattern discharge $15^{\circ}$ forward did not improve spray penetration in a peanut canopy. Ozkan et al. (2006) found that twin-fan discharge reduced spray deposits in a relatively tall, dense, narrow-row, soybean canopy. There is little information about the effectiveness of the twin-fan nozzle spray pattern in shorter and less dense vegetable canopies.

The effectiveness of air-induction nozzles in reducing spray drift is well-documented (Derksen et al., 1999); however, researchers know little about spray deposit characteristics of these nozzles inside a targeted canopy. Derksen et al. (2000) reported that foliar spray retention produced by airinduction nozzles was similar to that produced by traditional hollow-cone nozzles in an orchard canopy but that there were differences in observed spray coverage. In a comparison of different nozzle tips on spray penetration into peanut canopies, Zhu et al. (2004) found that a conventional flat-fan nozzle had the lowest spray penetration into the canopy and that an air-induction nozzle produced less deposit variation than twin-fan and conventional flat-fan nozzles.

The objectives of this research were to determine the influence of air-assisted delivery, charged sprays, spray patterns, and droplet sizes on the amount spray material and spray coverage on bell pepper leaves and fruit in plant spacing systems with different plant densities. In a companion study, Vitanza (2006) evaluated and reported on the biological influence of the plant density and application methods on fruit yield and quality.

\section{Material ANd Methods}

A randomized complete block (RCB) design containing nine treatments and four replications was prepared in 2004. The bell pepper plots (cv. 'Socrates') consisted of $18.3 \mathrm{~m}$ long twin rows of pepper plants and an untreated twin-row guard on each side, with replications separated by $9.1 \mathrm{~m}$ alleys. Test plots were arranged in bare-ground plots, in twin rows, with between-row and within-row distances of $46 \mathrm{~cm}$, in $13 \mathrm{~cm}$ high and $1.5 \mathrm{~m}$ wide beds. The soil was a Hoytville silty clay loam. The previous year's crop was corn.

In the 2005 trial, the research plot was in an area of Hoytville silty clay loam where the land had been fallow the previous year. The bell pepper plots (cv. 'Socrates') consisted of $7.6 \mathrm{~m}$ long single-row or twin-row plantings of pepper plants and a single, untreated guard row on each side, with $6.1 \mathrm{~m}$ alleys separating replications in a RCB design. Within-row plant spacing was $38 \mathrm{~cm}$ in single rows and both 38 and $51 \mathrm{~cm}$ in twin rows. Twin rows were $46 \mathrm{~cm}$ apart.

The 2004 and 2005 field trials included the nozzles and pressures described in table 1 . These treatments were selected to help evaluate a wide range of delivery options, including droplet size, air-assisted delivery, and charged spray delivery, that could be readily adopted by vegetable producers. In 2004, a conventional, broadcast boom sprayer, an airassist boom sprayer, and an air-assist electrostatic sprayer
Table 1. 2004 and 2005 Spray equipment parameters.

\begin{tabular}{|c|c|c|c|c|c|c|}
\hline \multirow[b]{2}{*}{ Nozzle } & \multirow{2}{*}{$\begin{array}{c}\text { Liquid } \\
\text { Pressure } \\
(\mathrm{kPa})\end{array}$} & \multirow{2}{*}{$\begin{array}{l}\text { Travel } \\
\text { Speed } \\
\left(\mathrm{km} \mathrm{h}^{-1}\right)\end{array}$} & \multicolumn{3}{|c|}{$\begin{array}{l}\text { Droplet Spectrum } \\
\text { Characteristics }\end{array}$} & \multirow{2}{*}{$\begin{array}{c}\text { Average } \\
\text { Drop } \\
\text { Speed } \\
\left(\mathrm{m} \mathrm{s}^{-1}\right)\end{array}$} \\
\hline & & & $\begin{array}{l}D_{\mathrm{V} .10} \\
(\mu \mathrm{m})\end{array}$ & $\begin{array}{l}D_{V .50} \\
(\mu \mathrm{m})\end{array}$ & $\begin{array}{l}D_{V .90} \\
(\mu \mathrm{m})\end{array}$ & \\
\hline \multicolumn{7}{|c|}{ Conventional nozzles } \\
\hline AI110025[a] & 521 & 6.4 & 132.0 & 394.5 & 687.5 & 4.60 \\
\hline AI11005[b] & 565 & 12.9 & 127.5 & 411.0 & 773.1 & 5.03 \\
\hline TJ60-11003[a] & 379 & 6.4 & 152.2 & 198.8 & 285.8 & 4.08 \\
\hline TJ60-11006[b] & 427 & 12.9 & 131.5 & 225.6 & 383.0 & 5.83 \\
\hline \multicolumn{7}{|l|}{ Air-assist nozzles } \\
\hline XR110015[a] & 690 & 6.4 & $71.4[\mathrm{c}]$ & $130.4^{[\mathrm{c}]}$ & $231.5^{[\mathrm{c}]}$ & $4.46^{[\mathrm{c}]}$ \\
\hline $\mathrm{XR} 11003[\mathrm{~b}]$ & 758 & 12.9 & $78.6^{[\mathrm{c}]}$ & $140.8^{[\mathrm{c}]}$ & $279.7[\mathrm{c}]$ & $7.14[\mathrm{c}]$ \\
\hline \multicolumn{7}{|c|}{ Air atomization and electrostatic nozzle } \\
\hline MaxCharge $[\mathrm{b}]$ & 276 & 6.4 & NA & NA & NA & NA \\
\hline
\end{tabular}

[a] 2004 and 2005 trials.

[b] 2004 trial only.

[c] Measured without air-assistance.

were used to make applications. The conventional, broadcast boom sprayer, mounted with a 3-point hitch, consisted of a non-air-assist, offset boom to treat plots on one side of the sprayer. It was set up to deliver $280.6 \mathrm{~L} \mathrm{ha}^{-1}$ of spray mix with nozzles spaced at $51 \mathrm{~cm}$.

The Myers Mity Mist (Myers, Ashland, Ohio) is a broadcast sprayer that uses air to assist in delivery of spray produced by the conventional flat-fan tips listed in table 1 . This sprayer resembles a conventional airblast orchard sprayer, but the airflow direction is reversed to move air out the back of the machine across a wet-boom in a broadcast arrangement. Metal ductwork attached to the fan outlet directs the air in a $6.1 \mathrm{~m}$ swath at approximately $30^{\circ}$ back from vertical behind the sprayer. The boom is in the center of the air duct, near the $20 \mathrm{~cm}$ wide air outlet. Average air speed across the outlet is approximately $20 \mathrm{~m} \mathrm{~s}^{-1}$ at rated PTO speed $(540 \mathrm{rpm})$. The Myers Mity Mist was equipped to deliver a volume of $280.6 \mathrm{~L} \mathrm{ha}^{-1}$, with nozzles spaced at $31 \mathrm{~cm}$.

The 2004 electrostatic sprayer provided by ESS (Electrostatic Spraying Systems, Inc., Watkinsville, Ga.) was specially designed to be a small-plot research version of a commercial model, mounted on a tractor with a 3-point hitch. The electrostatic sprayer had an offset boom to treat plots on one side of the sprayer. It was equipped with MaxCharge air-assist nozzles. These nozzles were spaced $18 \mathrm{~cm}$ apart and delivered a volume of $47.7 \mathrm{~L} \mathrm{ha}^{-1}$ at an air pressure of $207 \mathrm{kPa}$ and liquid pressure of $276 \mathrm{kPa}$. The MaxCharge air-shear nozzles use air to atomize the liquid spray and to aid in spray delivery as well as to help clean the charging ring in the nozzle tip, which helps maintain the efficiency of the charge transfer.

All sprayers used a nozzle height of approximately $0.46 \mathrm{~m}$ above the canopy. Travel speeds of 6.4 and $12.9 \mathrm{~km} \mathrm{~h}^{-1}$ were used for the air-assist and conventional boom sprayer treatments in 2004. The ESS sprayer with MaxCharge nozzles was only operated at $6.4 \mathrm{~km} \mathrm{~h}^{-1}$ in 2004 because the nozzle flow rate could not be increased to maintain the $47.7 \mathrm{~L} \mathrm{ha}^{-1}$ application rate. In the 2005 field trials, all three treatments traveled at a speed of $6.4 \mathrm{~km} \mathrm{~h}^{-1}$ (table 1).

A portable weather station was used to monitor wind speed, azimuth, ambient air temperature, and relative humidity. Results from each application date are shown in table 2. Because the test site was more than $2 \mathrm{~h}$ drive from the labora- 
Table 2. Daily meteorological conditions for tracer evaluations.

\begin{tabular}{|c|c|c|c|c|}
\hline $\begin{array}{c}\text { Application } \\
\text { Date }\end{array}$ & $\begin{array}{l}\text { Wind } \\
\text { Speed } \\
\text { Range } \\
\left(\mathrm{m} \mathrm{s}^{-1}\right)\end{array}$ & $\begin{array}{l}\text { Wind } \\
\text { Direction } \\
\text { Range } \\
\left(^{\circ}\right)\end{array}$ & $\begin{array}{c}\text { Ambient } \\
\text { Temp. } \\
\text { Range } \\
\left({ }^{\circ} \mathrm{C}\right)\end{array}$ & $\begin{array}{c}\text { Ambient } \\
\text { Relative } \\
\text { Humidity } \\
(\%)\end{array}$ \\
\hline 17 Aug. 2004 & $1.0-8.5$ & $84-314$ & $23.0-26.1$ & $39-63$ \\
\hline 27 Aug. 2004 & $1.0-8.5$ & $187-269$ & $27.0-28.3$ & $72-79$ \\
\hline 03 Sept. 2004 & $1.0-4.7$ & $92-307$ & $24.4-25.3$ & $68-77$ \\
\hline 16 Sept. 2004 & $1.7-9.2$ & $180-286$ & $24.8-25.8$ & $67-73$ \\
\hline 20 Sept. 2004 & $0-7.7$ & $61-257$ & $20.7-22.1$ & $31-41$ \\
\hline 21 Sept. 2004 & $0-4.7$ & $164-349$ & $22.0-23.2$ & $39-49$ \\
\hline 23 Sept. 2004 & $0-4.7$ & $57-365$ & $24.9-27.4$ & $36-54$ \\
\hline 28 Sept. 2004 & $0-9.2$ & $247-164$ & $18.0-19.9$ & $72-80$ \\
\hline 17 Aug. 2005 & $0-4.0$ & $347-201$ & $25.6-27.9$ & $45-70$ \\
\hline 24 Aug. 2005 & $0-4.7$ & $355-227$ & $20.6-22.3$ & $45-70$ \\
\hline 25 Aug. 2005 & $0-3.2$ & $337-129$ & $21.8-23.5$ & $56-64$ \\
\hline 07 Sept. 2005 & $1.9-4.7$ & $49-246$ & $23.7-24.3$ & $53-64$ \\
\hline 08 Sept. 2005 & $0-4.7$ & $264-12.6$ & $23.1-23.7$ & $62-68$ \\
\hline
\end{tabular}

tory where samples were processed, experiments were conducted over several days to minimize degradation of samples between the time they were collected and processed in the laboratory. Average conditions did not vary greatly between applications. Wind speed averaged less than $4.6 \mathrm{~m} \mathrm{~s}^{-1}$ on all days. The portable tripod weather station equipped for measuring wind speed and direction (model 03001 Wind Sentry Set, R. M. Young Inc., Traverse City, Mich.) was aligned for north and installed with the windset at a height of $2.3 \mathrm{~m}$. An air temperature and relative humidity probe (model HMP-45C, Campbell Scientific, Logan, Utah) was mounted at a height of $1.8 \mathrm{~m}$. Data were recorded every second with a micrologger (model CR23X, Campbell Scientific, Logan, Utah).

\section{Droplet Size and Velocity Measurement}

Droplet size distributions and droplet velocities from the three groups of nozzles were determined in the laboratory using a particle/droplet laser image analysis system (Oxford Lasers VisiSizer and PIV, Oxfordshire, U.K.) described by Güler et al. (2007). During the tests, the laser image analysis system setting was lens option 3 at magnification setting 1 . At this setting, the system could measure droplets from $42.8 \mu \mathrm{m}$ to $1023.7 \mu \mathrm{m}$. Droplet samples were taken $50 \mathrm{~cm}$ below the nozzle orifice and across the centerline along the long axis of the spray pattern by scanning within a $40 \mathrm{~cm}$ range. The measurement for each condition was replicated once. At least 10,000 droplets were sampled in each pass across the spray pattern. Particle image velocimetry (PIV) with 2D setting of the laser image analysis system was used to determine average velocities of all droplets passing through an $8 \times 8 \mathrm{~cm}$ area $50 \mathrm{~cm}$ below the nozzle orifice. Velocity measurement results were averaged from at least 20 pairs of frames.

\section{Canopy Density}

As an indirect method of estimating canopy density in bell peppers, the researchers measured the sunlight reaching the ground beneath the crop canopy at noon under a cloudless sky using a LI-1000 data logger (Li-Cor, Inc., Lincoln, Neb.) on 9 September 2005. To ensure consistent measurements across all plots, a Li-Cor model LQA1204 quantum sensor was placed on the ground along the row, midway along the plot length, touching the westward side of the bell pepper plant stems.

\section{Foliar and Fruit Spray Retention}

Spray retention or the amount of spray on leaves was determined by spraying a tank mix of water-soluble food coloring (FD\&C No. 1, Warner and Jenkinson, Inc., St. Louis, Mo.) at a concentration of $2 \mathrm{~g} \mathrm{~L}^{-1}$. After allowing the sprays to dry, three leaves were randomly collected from the middle and bottom levels on each of three plants per replicate and placed into a $125 \mathrm{~mL}$ glass bottle and capped. The quantity of food coloring on each leaf was determined by washing each leaf in $35 \mathrm{~mL}$ of distilled water and comparing the intensity of the emission at $620 \mathrm{~nm}$ with calibration solutions using a Lambda 10 UV/VIS spectrometer (Perkin-Elmer, Norwalk, Conn.). After rinsate samples had been drawn from leaf sample bottles, the leaves were removed from their storage bottles and the area of each leaf was determined using a video system (Delta-T, Cambridge, U.K.). These area measurements were doubled to account for areas on both upper and underside leaf surfaces.

Assessments of spray retention on fruit were made by randomly harvesting four mature pepper fruit from the bottom of each canopy in each replicate. Each fruit was placed in a 3.79 L, resealable plastic bag. Spray recovery from the fruit was made by washing each fruit with $35 \mathrm{~mL}$ of distilled water added to the resealable plastic storage bag and shaking the bag for $30 \mathrm{~s}$. After rinsate samples had been drawn from sample bags, fruit were removed from their containers and the size of each fruit, as denoted by the volume, was determined by using a water displacement test.

\section{Foliar Spray Coverage}

Spray quality was assessed by spraying a tank mix of $1.25 \mathrm{~g} \mathrm{~L} \mathrm{~L}^{-1}$ of water-soluble fluorescent dye (Tinopal CBS-X, Keystone, Chicago, Ill.) plus a $0.1 \%$ concentration of X-77 non-ionic spreader (Loveland Industries, Greeley, Colo.) on each plot. The surfactant was added to the tank mix because several of the pesticides used in a companion portion of this study, such as Assail 70WP (Cerexagri, Inc., King of Prussia, Pa.) and SpinTor 2SC (Dow AgroSciences, Indianapolis, Ind.), recommended use of a non-ionic surfactant to enhance spray coverage. Following a 5 min drying period, three leaves were randomly collected from the middle and bottom levels of each of three plants per replicate and laid flat in individual paper bags.

Spray coverage evaluations were made in a laboratory using an Eclipse E-400 epi-fluorescent microscope (Nikon, Tokyo, Japan) with a $2 \times$ objective. Filter sets used for illuminating the dried tracer and limiting natural auto-fluorescence emitted from the leaves included an excitation filter (360 to $400 \mathrm{~nm}$ ), a dichroic mirror (400 nm), and a barrier filter (460 to $510 \mathrm{~nm}$ ) that limited fluorescent light generated by the specimen. To help minimize focusing errors, a vacuum stage was used to hold the samples flat under the microscope. Images were captured and digitized using a SPOT RT monochrome, air-cooled camera (Diagnostic Instruments, Inc., Sterling Heights, Mich.). The sample area for coverage measurements was $5.6 \times 4.23 \mathrm{~mm}(1600 \times 1200$ pixels $)$. The camera operator attempted to identify a sample area that generally represented the type of coverage observed across the entire leaf surface. Images were processed in batch files for each replicate using the technique described by Ramalingam et al. (2003). 
A randomized complete block design containing four replications was employed each year to evaluate spray application technologies. Treatment means from the year 2005 trial were compared to corresponding treatments from the year 2004 trial. Results were tested by analysis of variance, and LSD values were used for means separation (SAS, 2004).

\section{Results AND Discussion}

\section{Droplet Size and Velocity Measurement}

Droplet size characteristics and droplet velocities for the spray systems tested are shown in table 1. Droplet size was not measured for the MaxCharge nozzle. For the same nozzle type, droplet velocity increased with increasing droplet size. The XR110015 nozzle is rated to produce the same flow rate at 275 $\mathrm{kPa}$ as the individual orifices of the TJ60-11003 nozzle with dual-fan orifices. However, because the XR110015 nozzle was operated at a much higher pressure, the droplet size was smaller (130.4 vs. $198.8 \mu \mathrm{m})$ and the droplet velocity was higher (4.46 vs. $4.08 \mathrm{~m} \mathrm{~s}^{-1}$ ) than the TJ60-11003 nozzle. Similar differences were observed between the XR11003 and TJ60-11006 nozzles. The AI nozzle series is characterized as a low-drift nozzle by the manufacturer. Lab measurements illustrated that under the conditions of this study, these nozzles produced the largest droplet spectrums.

\section{CANOPY Density}

Mature canopies varied in height from 40 to $46 \mathrm{~cm}$ in each year. Light intensity readings across row planting treatments are shown in table 3 for the 2005 trials. Sunlight at ground level under the crop canopy was more intense in single rows than in twin rows planted within row spacing of $38 \mathrm{~cm}$. Light intensity was not significantly different between the twinrow planting systems or between the single-row and twinrow planting system with wider plant spacing.

\section{Foliar ANd Fruit Spray Retention}

Figure 1 shows the mean spray retention or the amount of spray on the foliage for the 2004 treatments and the standard
Table 3. Light intensity readings 9 September 2005.

\begin{tabular}{cc}
\hline Treatment & Reading $\left(\mu \mathrm{M} \mathrm{s}^{-1} \mathrm{~m}^{-2}\right)^{[\mathrm{a}]}$ \\
\hline Single row $-38 \mathrm{~cm}$ & $151.5 \mathrm{a}$ \\
Twin row $-38 \mathrm{~cm}$ & $65.5 \mathrm{~b}$ \\
Twin row $-51 \mathrm{~cm}$ & $90.8 \mathrm{ab}$ \\
\hline p-value & 0.031 \\
LSD & 73.4 \\
\hline
\end{tabular}

[a] Values followed by the same lowercase letter are not significantly different $(\mathrm{p}<0.05)$.

error bars associated with each mean. All treatments deposited more material in the middle canopy area than the bottom of the canopy despite there being only about $25 \mathrm{~cm}$ distance between the two sampling zones. There were no significant differences in canopy deposits for any particular nozzle type or sprayer type operated at the two different travel speeds evaluated (6.4 and $12.9 \mathrm{~km} \mathrm{~h}^{-1}$ ). The Myers Mity Mist air-assist sprayer using the XR110015 nozzles produced significantly lower deposits than all the other treatments in the middle of the canopy except for the higher speed air-assist sprayer. There were no significant differences in middle canopy deposits between any of the applications made with all conventional broadcast sprayer treatments and the electrostatic sprayer using MaxCharge nozzles. Figure 1 also shows that the conventional sprayer using the TJ60-11006 nozzles at $12.9 \mathrm{~km} \mathrm{~h}^{-1}$ produced significantly higher deposits in the bottom canopy area than all other treatments except for the conventional sprayer treatment using the TJ60-11003 nozzles. Otherwise, there were no significant differences in foliar spray retention in the bottom area of the canopy among the electrostatic, air-assist, and conventional sprayer using air-induction nozzles at any travel speed.

Fewer sprayer treatments were evaluated in 2005, but plant density was also investigated (fig. 2). All treatments were made at $6.4 \mathrm{~km} \mathrm{~h}^{-1}$. The TJ60-11003 nozzle, treating the twin-row system with $51 \mathrm{~cm}$ within-row spacing, produced significantly higher spray retention on leaves taken from the middle of canopy than all other treatments. There were no significant differences in spray retention found in the middle of the pepper canopy between any of the other treatments.

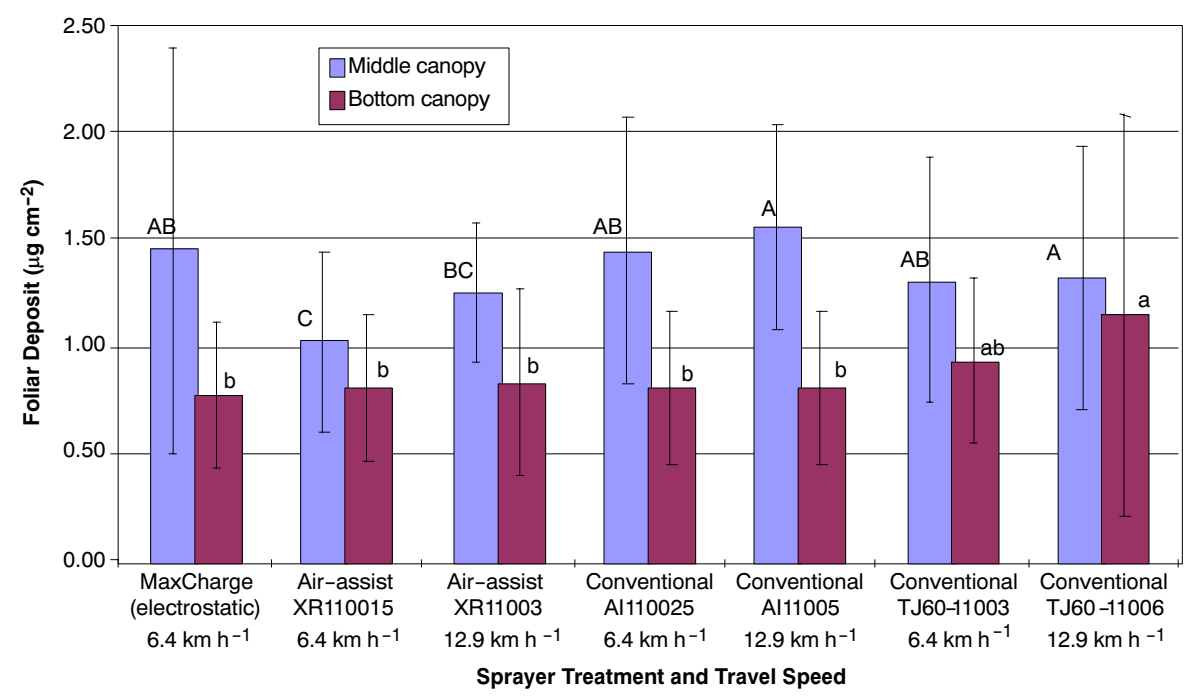

Figure 1. 2004 Spray retention on pepper leaves across application systems and travel speeds. Uppercase letters represent significant difference (p < 0.05 ) among spray deposits at the middle canopy position. Lowercase letters represent significant difference (p < 0.05$)$ among spray deposits at the bottom canopy position. Error bars represent standard deviations of means. 


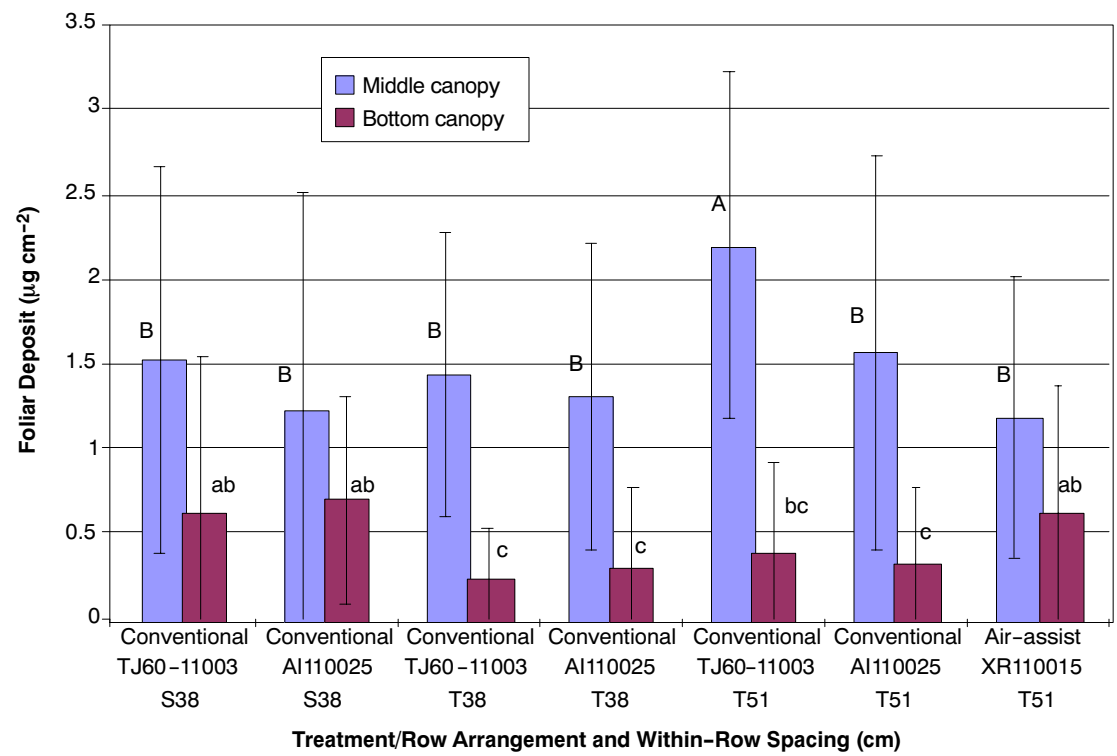

Figure 2. 2005 Foliar spray retention by sprayers across different pepper planting systems by number of rows and spacing within rows ( $\mathrm{S}=$ single row; $T=$ twin row). Uppercase letters represent significant difference $(p<0.05)$ among spray deposits at the middle canopy position. Lowercase letters represent significant difference $(\mathrm{p}<\mathbf{0 . 0 5})$ among spray deposits at the bottom canopy position. Error bars represent standard deviations of means.

Table 4. Middle canopy foliar spray retention comparison by years.

\begin{tabular}{lccc}
\hline & \multicolumn{3}{c}{ Foliar Deposit $\left(\mu \mathrm{g} \mathrm{cm}^{-2}\right)^{[\mathrm{a}]}$} \\
\cline { 2 - 4 } Treatment & 2004 & 2005 & $\begin{array}{c}\text { Combined } \\
\text { Years }\end{array}$ \\
\hline Conventional, TJ60-11003 & $1.31 \mathrm{a}$ & $2.19 \mathrm{a}$ & $1.75 \mathrm{a}$ \\
Conventional, AI110025 & $1.45 \mathrm{a}$ & $1.57 \mathrm{~b}$ & $1.51 \mathrm{a}$ \\
Air-assist, XR110015 & $1.02 \mathrm{~b}$ & $1.18 \mathrm{c}$ & $1.10 \mathrm{~b}$ \\
\hline LSD & 0.24 & 0.38 & 0.38 \\
p-value & 0.0019 & $<0.0001$ & 0.0152
\end{tabular}

[a] Values in the same column followed by the same lowercase letter are not significantly different $(\mathrm{p}<0.05)$.
Table 5. Bottom canopy foliar spray retention comparison by years.

\begin{tabular}{lccc}
\hline & \multicolumn{3}{c}{ Foliar Deposit $\left.(\mu \mathrm{g} \mathrm{cm})^{-2}\right)^{[\mathrm{a}]}$} \\
\cline { 2 - 4 } Treatment & 2004 & 2005 & $\begin{array}{c}\text { Combined } \\
\text { Years }\end{array}$ \\
\hline Conventional, TJ60-11003 & $0.93 \mathrm{~ns}$ & $0.38 \mathrm{~ns}$ & $0.66 \mathrm{~ns}$ \\
Conventional, AI110025 & $0.80 \mathrm{~ns}$ & $0.32 \mathrm{~ns}$ & $0.56 \mathrm{~ns}$ \\
Air-assist, XR110015 & $0.81 \mathrm{~ns}$ & $0.62 \mathrm{~ns}$ & $0.71 \mathrm{~ns}$ \\
\hline LSD & 0.17 & 0.28 & 0.28 \\
p-value & 0.24 & 0.08 & 0.43 \\
\hline
\end{tabular}

[a] ns = No significant differences in the same column.

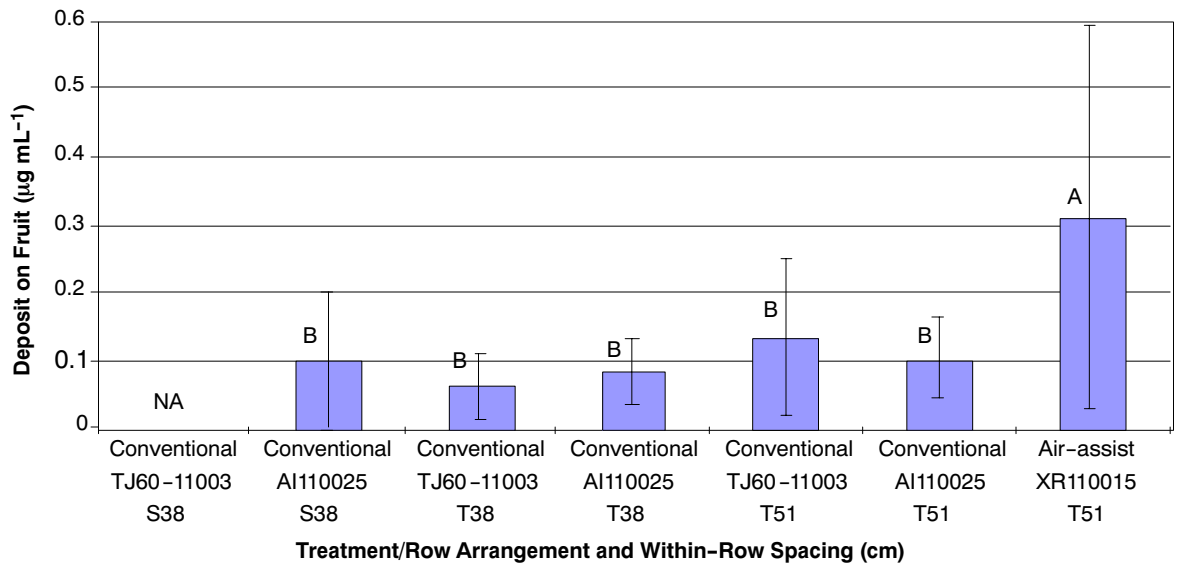

Figure 3. 2005 Spray retention on pepper fruit across different planting systems by number of rows and spacing within rows $(S=$ single row; $T=$ twin row). Uppercase letters represent significant difference $(p<0.05)$ among spray deposits on mature pepper fruit. Error bars represent standard deviations of means.

Canopy density affected spray deposits significantly in the lower portions of the pepper canopies. Figure 2 shows that in general, spray retention was lower in twin-row canopies treated by the TJ60-11003 and AI110025 nozzles than in the single-row canopies. The air-assist treatment using XR110015 nozzles produced more spray retention in the denser, twin-row canopies than most of the conventional broadcast sprayer treatments. There was no significant difference in spray retained in the bottom canopy area in the single-row treatments treated with $\mathrm{TJ}$ and $\mathrm{AI}$ nozzles and the twin-row planting $(51 \mathrm{~cm})$ treated by the air-assist treatment.

The TJ60-11003, AI110025, and air-assist XR110015 nozzle treatments were used in both 2004 and 2005 bell pep- 


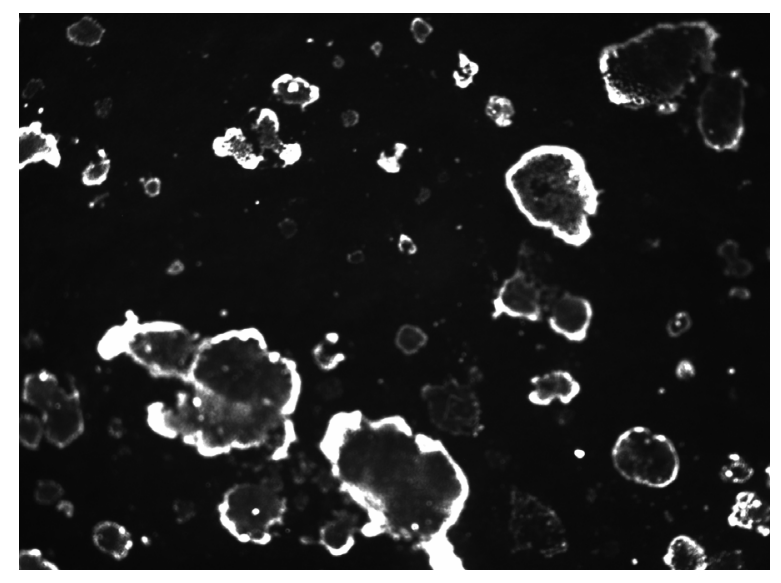

(a)

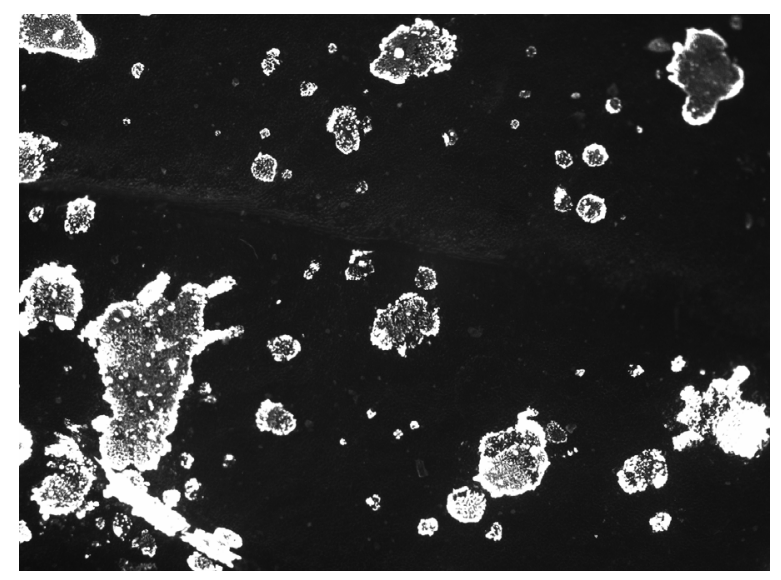

(c)

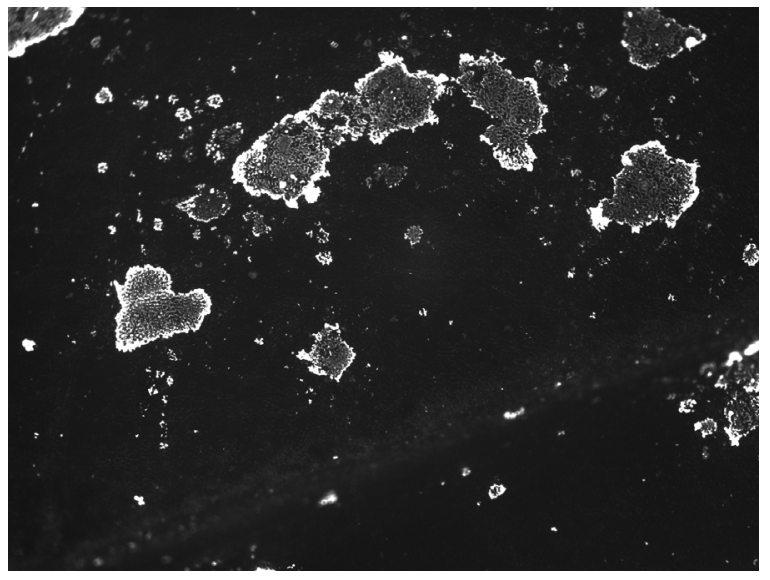

(e)

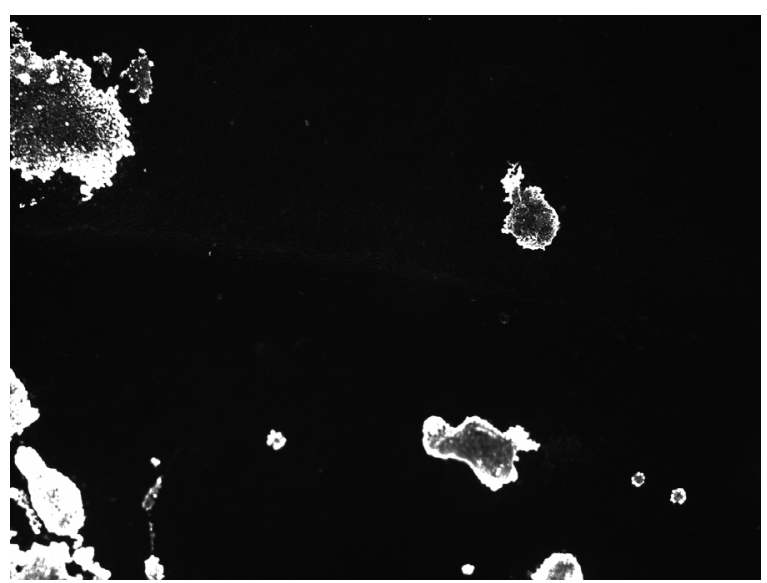

(b)

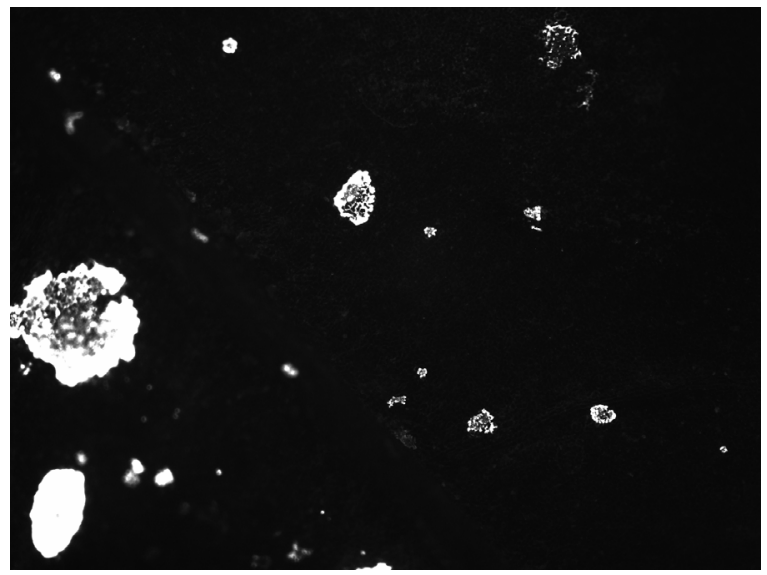

(d)

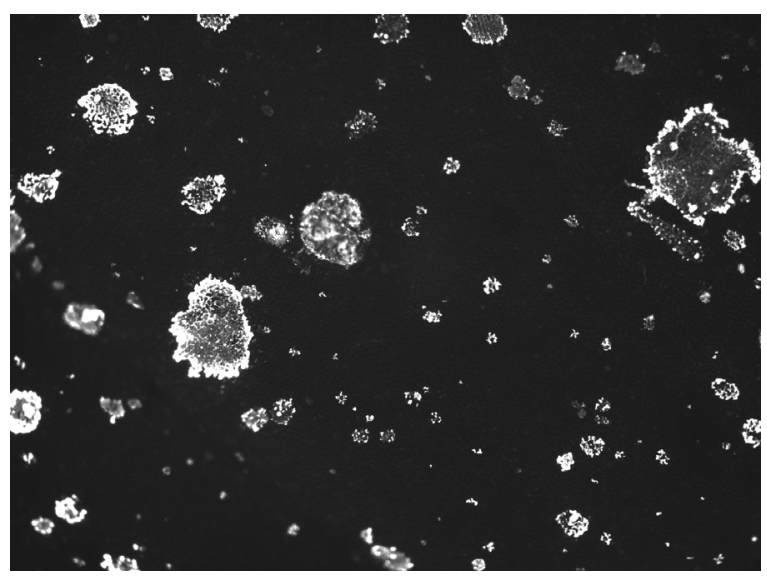

(f)

Figure 4. Image representing average upper leaf surface coverage: (a) AI110025 middle canopy, (b) AI110025 bottom canopy, (c) TJ60-11003 middle canopy, (d) TJ60-11003 bottom canopy, (e) air-assist XR110015 middle canopy, (f) air-assist XR110015 bottom canopy.

per field trials. All sprayers were operated at a travel speed of $6.4 \mathrm{~km} \mathrm{~h}^{-1}$. All applications were made at a rate of $280.6 \mathrm{~L}$ $\mathrm{ha}^{-1}$. Table 4 shows that there were significant differences in middle canopy foliar spray retention among the three treatments in 2005, but there were no differences in the spray retention between two conventional sprayer treatments (TJ60-11003 and AI110025) in 2004. Combined across years, spray retention was higher on middle canopy foliage treated by the conventional sprayer with TJ60-11003 and AI110025 nozzles than the air-assist sprayer treatment. This could have resulted from the spray from the Myers air-assist sprayer being blown beyond the middle canopy area.

Table 5 shows statistical comparisons of the spray retained on foliage in the bottom of the pepper canopies in 2004 and 2005. There were no significant differences in foliage spray retention between the treatments in 2004 and 2005 and combined across years. 


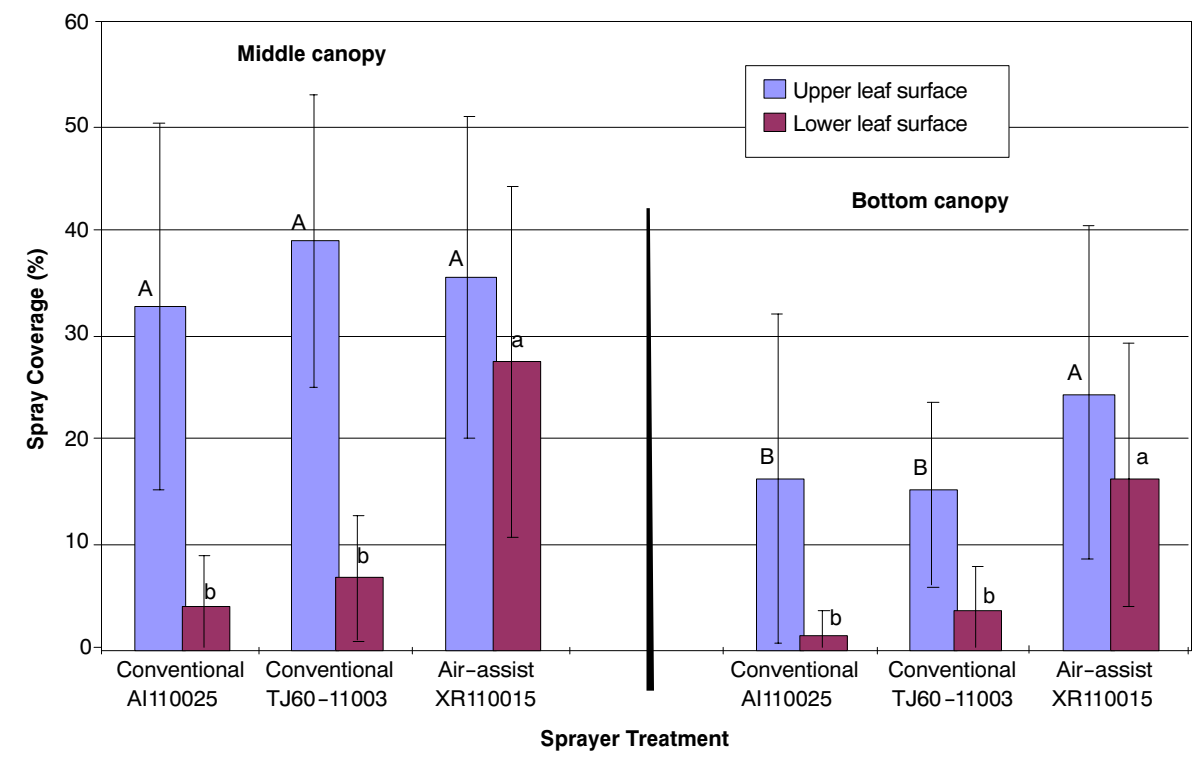

Figure 5. Percent spray coverage on pepper leaves in 2005 twin-row pepper field trial. Uppercase letters represent significant difference (p < 0.05 ) among spray coverage on upper leaf surfaces within each canopy position. Lowercase letters represent significant difference (p < 0.05 ) among spray coverage on lower leaf surfaces within each canopy position. Error bars represent standard deviations of means.

All of the mature peppers in 2004 and 2005 were found at the bottom of the canopy near the ground. Mature fruit was generally closer to the ground than the lowest leaves in the canopy. Figure 3 shows spray retained on fruit in 2005. Significantly higher deposits were produced on fruit in the twinrow $51 \mathrm{~cm}$ spacing by the air-assist sprayer using XR110015 nozzles than the conventional, broadcast sprayer treatments. There were no significant differences in spray retention between any of the planting systems using the conventional, broadcast TJ60-11003 and AI110025 nozzles.

\section{Foliar Spray Coverage}

Foliar spray coverage evaluations were made in the 2005 twin-row spacing trial. Figure 4 shows photographs that represent the average percent area of leaf surface coverage found on the upper surface of leaves taken from the middle canopy area. It was not always possible to clearly define the continuous boundary of a larger blob because of the drying pattern of the droplets. The photographs show that what could be considered the interior of some blobs was difficult to distinguish from the untreated leaf background. Areas that would appear to be large blobs to a trained user were often analyzed as an area of small features. The percent area of coverage was based on those pixel features that could be differentiated from the background without consideration of whether the feature was a portion of a neighboring feature. The processing software also identified relevant features or blobs in photographs that could not be easily identified with the naked eye.

Figure 5 shows the coverage measured on the upper and lower surfaces of leaves taken from the middle and bottom

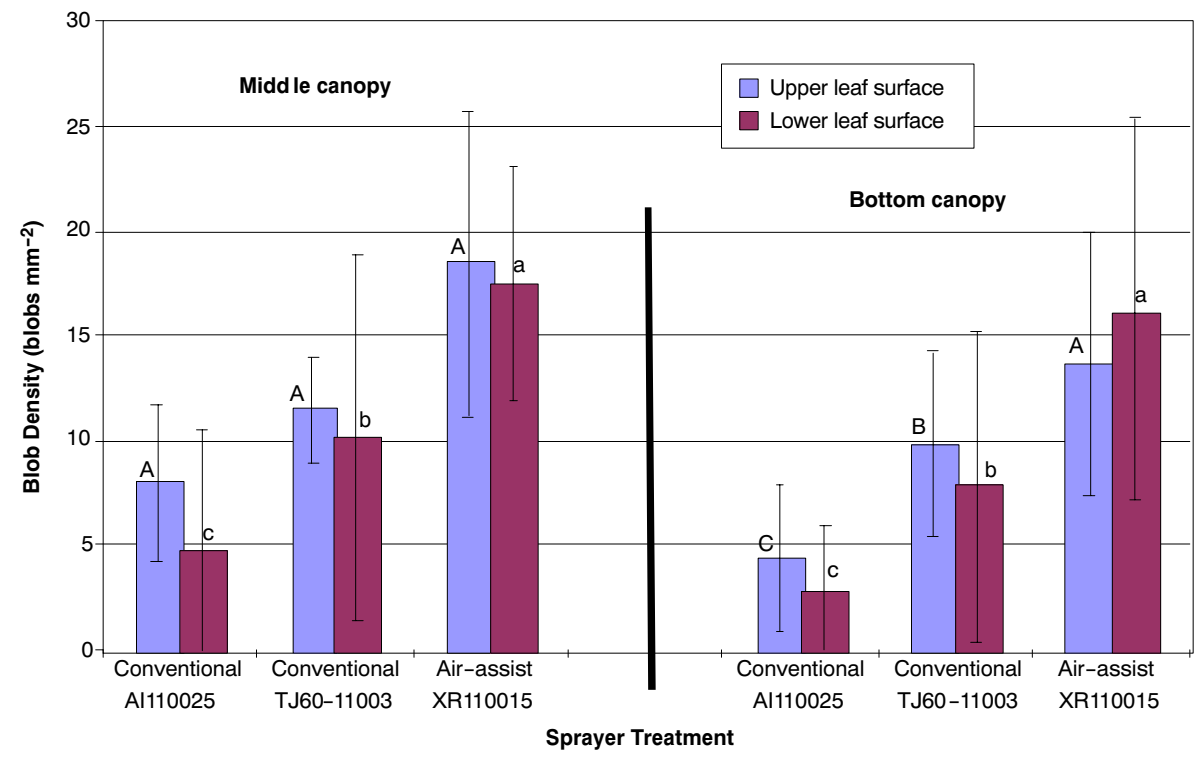

Figure 6. Spray blob density on pepper leaves in 2005 twin-row pepper field trial. Uppercase letters represent significant difference (p $<0.05)$ among blob density on upper leaf surfaces within each canopy position. Lowercase letters represent significant difference $(p<0.05)$ among blob density on lower leaf surfaces within each canopy position. Error bars represent standard deviations of means. 
canopy areas. There were no differences between the three treatments in spray coverage measured on the upper surfaces of leaves taken from the middle canopy area. The air-assist treatment produced more than three times the coverage than the two conventional, broadcast sprayer treatments on the lower surfaces of leaves taken from the middle of the pepper canopy. In the bottom of the canopy, leaves treated by the airassist sprayer using the XR110015 nozzles had significantly higher spray coverage than either the AI110025 or TJ60-11003 treatments. As found in the middle of the canopy, the air-assist sprayer produced more than three times greater coverage than the AI or TJ conventional nozzle treatments on the underside leaf surfaces taken from the bottom of the canopy.

Figure 6 shows the density of blobs or spots observed on leaves measured for spray coverage for each of the three twin-row treatments. The air-assist sprayer treatment produced the highest blob density on all leaf surfaces except the upper surfaces of leaves taken from the middle of the canopy. Leaves treated by the TJ60-11003 treatment produced significantly greater blob densities than the AI110025 nozzles on a conventional sprayer except for the upper surfaces of leaves taken from the middle canopy. The blob density appeared to be directly related to the droplet size produced by each treatment. Blob density increased as droplet size decreased. As shown in table 1 , the $D_{V .50}$ measured $50 \mathrm{~cm}$ below the nozzles for the air-assist XR110015, TJ60-11003, and AI110025 nozzles were $130.4,198.8$, and $394.5 \mu \mathrm{m}$, respectively.

\section{SuMmaRY AND CONCLUSIONS}

Vitanza (2006) reported few differences in pepper yield or biological efficacy (i.e., caterpillars, bacterial spot, end rot) between the 2004 and 2005 treatments. All treatments produced statistically higher yields than the untreated check plot. The electrostatic sprayer using the MaxCharge nozzles produced the overall lowest marketable yields in the twinrow system in 2004, but this did not correlate with foliar spray retention results compared to other treatments. There were few differences in foliar spray retention between treatments used in the 2004 and 2005 trials. Travel speed (6.4 vs. $12.9 \mathrm{~km} \mathrm{~h}^{-1}$ ) did not produce significant differences in deposits in these pepper canopies. Smaller droplet TJ and larger droplet AI nozzles produced relatively small differences in foliar spray retention in these studies. This result was similar to those reported by Derksen et al. (2000) in an orchard comparing small droplet and large droplet nozzles but different from other studies that demonstrated differences in canopy spray retention by different nozzle types. While Zhu et al. (2004) reported that flat-fan nozzles produced the lowest spray penetration into a peanut canopy, it is not clear from these studies if commonly used flat-fan or cone hydraulic nozzles would produce any greater spray penetration into the same pepper canopy conditions used in these field trials.

Unlike previous studies in taller and denser canopies (Derksen et al., 2001; Mueller et al., 2002; Piché et al., 2000; Womac et al., 1992), the air-assist sprayer technology used to treat the relatively short pepper canopy provided no advantages in terms of canopy spray retention than the conventional broadcast treatments. The air speed may have been too fast to deposit material in the upper canopy area.
Deposits on the fruit demonstrated that air-assistance provided better canopy penetration, resulting in significantly higher deposits than the conventional sprayer treatments. There were no significant differences in spray retention on the fruit between any of the conventional sprayer treatments.

In general, plant density had little effect on spray deposits measured in the middle canopy area of the pepper plants. More spray was found on foliage lower in the canopy in the less dense, single-row planting system and in the twin-row canopy treated with the air-assist sprayer.

The greatest differences between treatments were in the spray quality measured on the leaves. The air-assist sprayer using the XR110015 nozzle produced greater spray coverage on the lower or underside leaf surfaces and in the lower portions of the canopy than either of the conventional sprayer treatments. The air-assist sprayer treatment also produced significantly higher dried droplet or blob density on the underside leaf surfaces and in the lower portions of the canopy than either of the conventional sprayer treatments. The smaller droplet TJ60-11003 nozzle produced higher dried droplet or blob density on the underside leaf surfaces than the larger droplet AI110025 nozzle, but that difference did not produce an overall difference in the pepper leaf surface spray coverage.

Taking into account measures of the amount of spray material on foliar and fruit and the spray coverage on leaves, the air-assist treatment performed better than the other treatments. Based on differences in results between application technologies used in this study and in previous application research in cotton, soybean, cantaloupe, and other canopies, it appears that canopy structure and density may affect canopy deposition more than sprayer type.

\section{ACKNOWLEDGEMENTS}

The authors thank Matt Hofelich and the staff at The Ohio State University, North Central Agricultural Research Station for their assistance in preparing, planting, and maintaining the plots used in these trials. The authors also appreciate the help of Andy Doklovic and Dan Troyer in preparing the equipment for the field trial and for collecting meteorological information; the help of Leslie Morris, Tony Karcher, and other Application Technology Research Unit staff in collecting field samples and analyzing spray retention and coverage samples; and Barry Nudd for measuring spray spectrum characteristics.

\section{REFERENCES}

Azimi, A. H., T. G. Carpenter, and D. L. Reichard. 1985. Nozzle spray distribution for pesticide application. Trans. ASAE 28(5): 1410-1414.

Batal, K. M., and D. A. Smittle. 1981. Response of bell pepper to irrigation, nitrogen, and plant population. J. American Soc. Hort. Sci. 106: 259-262.

Coates, W., and J. Palumbo. 1997. Deposition, off-target movement, and efficacy of Capture and Thiodan applied to cantaloupes using five sprayers. Trans. ASAE 13(2): 181-188.

Derksen, R. C., H. E. Ozkan, R. D. Fox, and R. D. Brazee. 1999. Droplet spectra and wind tunnel evaluation of venture and pre-orifice nozzles. Trans. ASAE 42(6): 1573-1580.

Derksen, R. C., R. D. Fox, R. D. Brazee, and C. R. Krause. 2000. Coverage and drift produced by air induction and conventional hydraulic nozzles used for orchard applications. ASAE Paper No. 001137. St. Joseph, Mich.: ASAE. 
Derksen, R. C., S. A. Miller, H. E. Ozkan, and R. D. Fox. 2001. Spray deposition characteristics on tomatoes and disease management as influenced by droplet size, spray volume, and air-assistance. ASAE Paper No. 011120. St. Joseph, Mich.: ASAE.

Ebert, T. A., R. C. Derksen, R. A. Downer, and C. R. Krause. 2004. Comparing greenhouse sprayers: The dose-transfer process. Pest Manag. Sci. 60(5): 507-513.

Gaye, M. M., P. A. Jolliffe, and A. R. Maurer. 1992. Row cover and population density effects on yield of bell peppers in south coastal British Columbia. Canadian J. Plant Sci. 72: 901-909.

Giles, D. K., and T. C. Blewett, 1991. Effects of conventional and reduced-volume, charged-spray application techniques on dislodgeable foliar residue of captan on strawberries. J. Agric. Food Chem. 39(9): 1646-1651.

Güler, H., H. Zhu, H. E. Ozkan, R. C. Derksen, Y. Yu, C. R. Krause. 2007. Spray characteristics and drift reduction potential with air induction and conventional flat-fan nozzles. Trans. ASABE 50(3): 745-754.

Herzog, G. A., W. R. Lambert, S. E. Law, W. E. Seigler, and D. K. Giles. 1983. Evaluation of an electrostatic spray application system for control of insect pests in cotton. J. Econ. Entomology 76(3): 637-640.

Himel, C. M. 1969. The optimum size of insecticide spray droplets. J. Econ. Entomology 62: 919-925.

Jeffers, D. L., A. F. Schmitthenner, and D. L. Reichard. 1982. Seed-borne fungi, quality, and yield of soybeans treated with benomyl fungicide by various application methods. Agron. J. 74: 589-592.

Jolliffe, P. A., and M. M. Gaye. 1995. Dynamics of growth and yield component responses of bell peppers (Capsicum annuum L.) to row covers and population density. Scientia Hort. 62(3): 153-164.

Locascio, S. J., and W. M. Stall. 1994. Bell pepper yield as influenced by plant spacing and row arrangement. J. American Soc. Hort. Sci. 119(5): 899-902.

Mueller, D. S., A. E. Dorrance, R. C. Derksen, E. Ozkan, J. E. Kurle, C. R. Grau, J. M. Gaska, G. L. Hartman, C. A. Bradley, and W. L. Pedersen. 2002. Efficacy of fungicides on Sclerotinia sclerotiorum and their potential for control of Sclerotinia stem rot on soybean. Plant Disease 86(1): 26-31.

Ozkan, H. E., H. Zhu, R. C. Derksen, H. Güler, and C. R. Krause. 2006. Evaluation of various spraying equipment for effective application of fungicides to control Asian soybean rust. In Aspects of Applied Biology 77: International Advances in Pesticide Applications 2006, 423-431. Warwick, U.K.: Association of Applied Biologists.
Perez, C. J., A. M. Shelton, and R. C. Derksen. 1995. Effect of application technology and Bacillus thringiensis subspecies on management of $B$. thuringiensis subsp. kurstaki-resistant diamondback moth (Lepidoptera: Plutellidae). J. Econ. Entomol. 88(5): 113-1119.

Piché, M., B. Panneton, and R. Thériault. 2000. Field evaluation of air-assisted boom spraying on broccoli and potato. Trans. ASAE 43(4): 793-799.

Ramalingam, N., P. P. Ling, and R. C. Derksen. 2003. Dynamic segmentation for automatic spray deposits analysis on uneven leaf surfaces. Trans. ASAE 46(3): 893-900.

Russo, V. M. 1991. Effects of fertilizer rate, application timing, and plant spacing on yield and nutrient content of bell pepper. $J$. Plant Nutr. 14(10): 1047-1056.

SAS. 2004. SAS/STAT 9.1. User's Guide. Cary, N.C.: SAS Institute, Inc.

Smith, D. B. 1992. Uniformity and recovery of broadcast sprays using fan nozzles. Trans. ASAE 35(1): 39-44.

Smith, D. B., D. Oakley, E. Williams, and A. Kirkpatrick. 2000. Broadcast spray deposits from fan nozzles. Trans. ASAE 16(2): 109-113.

Stofella, P. J., and H. H. Bryan. 1988. Plant population influences growth and yield of bell pepper. J. American Soc. Hort. Sci. 113(6): 835-839.

Vitanza, S. 2006. Unpublished data. El Paso, Tex.: Texas A\&M University.

Welty, C., S. Alcaraz, and H. E. Ozkan. 1995. Evaluating insecticide application techniques to control aphids in vegetable leaf crops. Hort Tech. 5(4): 317-326.

Womac, A. R., J. E. Mulrooney, and W. P. Scott. 1992. Characteristics of air-assisted and drop-nozzle sprays in cotton. Trans. ASAE 35(5): 1369-1376.

Zehnder, G. W., and J. Speese III. 1991. Evaluation of various spray nozzle and volume combinations for control of Colorado potato beetle (Coleoptera: Chrysomelidae) with synthetic and biological insecticides. J. Econ. Entomol. 84(6): 1842-1849.

Zhu, H., D. L. Rowland, J. W. Dorner, R. C. Derksen, and R. B. Sorensen. 2002. Influence of plant structure, orifice size, and nozzle inclination on spray penetration into peanut canopy. Trans. ASAE 45(5): 1285-1301.

Zhu, H., J. W. Dorner, D. L. Rowland, R. C. Derksen, and H. E. Ozkan. 2004. Spray penetration into peanut canopies with hydraulic nozzle tips. Biosystems Eng. 87(3): 275-283.

Zhu, H., R. D. Brazee, R. C. Derksen, R. D. Fox, C. R. Krause, H. E. Ozkan, and K. Losely. 2006. A specially designed air-assisted sprayer to improve spray penetration and air jet velocity distribution inside dense nursery crops. Trans. ASABE 49(5): 1285-1294. 
